\title{
Are Profitability and Investment Good Proxies for Risk Factors? The Analysis on Fama and French's Five-Factor Model
}

\author{
Zheng Huang \\ School of Business, Macau University of Science and Technology, Taipa, Macau \\ E-mail: huangzheng1989@aliyun.com
}

\begin{abstract}
The aim of this paper is to review a five-factor asset pricing model developed by Fama and French, which extends the three-factor model by incorporating two additional indicators that captured profitability and investment in average stock returns. Moreover, this paper provides a detail discussion and addresses some important issues and problems in capital asset pricing are becoming considerable topics for academic and practical research into the future.
\end{abstract}

Keywords-Fama and French; five-factor model; asset pricing; anomalies

\section{INTRODUCTION}

Capital asset pricing has now emerged as an active and flourishing content of finance, with the ambition of offering insights into the causes of the ever-growing anomalies in major empirical researches, and capital asset pricing problems are solved by judiciously choosing how much absolute and how much relative pricing one will do, depending on the assets in question and the purpose of the calculation [4]. It is well established that most of the crosssection variation in stock returns can be captured empirically by the classical three Fama-French factors [6]. The threefactor model elucidates definitely why a particular stock experience as a higher return than another stock overtime.

Recently, the new asset pricing model was proposed by Fama and French, which extended the three-factor model by incorporating two additional factors that captured profitability, and investment. Such an audacious attempt at confronting asset pricing theories with data requires a critical look. This motivates this review of their article, focusing on the anomalies that arise both in this context and more generally in recent asset pricing research. A wide range of questions in my mind arises spontaneously: what is the function of two factors and why they have to been added into their three-factor model. The rest of sections in this essay give us a complete and more-subtle interpretation.

This paper is organized as follows. Section 2 begins by discussing the theory and where the capital asset pricing models originated from, and shortly introduces how the fivefactor model is implemented and applied. Section 3 assesses methodology against the five-factor model. Section 4 discusses the empirical results of the five-factor model and a few limitations and questions in this process facing future researches. Section 5 offers some concluding remarks.

\section{BACKGROUND}

\section{A. Captial Asset Pricing Model}

The relationship between risk and return has long been a topic for capital asset pricing research. Since the mid of 1980s, there is now a substantial body of empirical studies in financial economics that has reported patterns in average stock returns that are inconsistent with the CAPM [22]. The beta is the measure of how much each stock moved in relation to the stock market as a whole, however, it has been not documented to be an incomplete measure risk. In particular, the price-earnings, small-firm, book-to-market, momentum, and long-term reversal effects are currently among the most puzzling phenomena in empirical tests. Therefore, a plethora of studies indicate this model is insufficient in explaining the expected stock returns and no longer can afford to give a reasonable approximation to the pricing of stock market securities.

To test the proposed theories, empirical researchers have to specify the empirical counterpart of the theoretical risk factors. Fama and French's (1993) seminal study introduces a pricing model that includes, along with the market return, two additional variables related to firm size (SMB) and book-to-market value ratio (HML) [6]. This three-factor model can explain the cross-section of equity returns much better than the CAPM, and the results show that how stocks behave and work backwards to uncover which characteristics explain the differences. They find evidence in the stock markets that small capitalization stocks and high book-tomarket stocks have higher returns than those calculated by the CAPM. Since then, tremendous empirical work has examined the validity of this three-factor model, in that it does not explain additional anomalies nor the cross-sectional variation in expected returns particularly related to Momentum [14], net share issues [13, 16], accruals [23], and volatility [2] as eminent instances. These phenomena are evidence of inefficient markets, more specifically, of systematic errors in the forecasts of stock analysts [15]. Previous researches were trying to interpret the ever-growing anomalies in the decades, but in fact, the potential problem with those interpretations was that stock markets are grossly inefficient, allowing for simplistic trading rules to offer large profit opportunities.

\section{B. A Five-factor Asset Pricing Model}

Recently, an article published in the Journal of Financial Economics has, for the first time, directly captured the size, value, profitability, and investment patterns. As in Fama and 
French (2015), the new model performs better than the threefactor model in average stock returns [5]. Fama and French (2015) investigate whether these new factors improve explanatory power and uncover profitability and investment effects. They denote "much of the variation in average returns due to profitability and investment is left unexplained by the three-factor model" [5].

The theoretical starting point of this paper organized differently by Fama and French is the dividend discount model [18], which should predict stock prices today and describe that the market value of one stock today will be the sum (the discounted present value) of all its future dividends. Equation (1) tries to tell us that higher excepted earnings insinuate higher excepted returns, because book-to-market ratio $(\mathrm{B} / \mathrm{M})$, as a noisy proxy, captures the information about excepted cash flows and discount rates.

$$
\frac{M_{t}}{B_{t}}=\frac{\sum_{t-1}^{\infty} E\left(Y_{t+\tau}-d B t_{t+\tau}\right) /(1+\tau)^{\tau}}{B_{\tau}}
$$

Actually, the Miller and Modigliani's valuation formula implies a set of basic relations between future stock returns, current B/M, firm-level expected profitability, and firm-level expected investment [9]. However, their work is unsuccessful to discover the predicted negative relation between expected investment and stock returns after controlling for the other two variables. In fact, their tests examine per share measures of expected investment and profitability and the valuation formula does not necessarily hold in per share analysis. While investment can be measured by either asset growth or equity growth, share issuance and repurchase will change the number of shares outstanding and per share growth can differ from the firmlevel growth.

As we all know, most of companies significantly increase capital investment tend to achieve sub-par subsequent returns [24], because the three factors miss much of the variation in average returns related to profitability and investment. Therefore, Aharoni, Grundy, and Zeng (2013) retreat to the Fama and French's conventional analysis and testify a weaker but statistically reliable relation between investment and average return at the firm level.

In five factor Fama-French model, they also extract some implications via the Miller and Modigliani valuation formula for the relations between expected returns, profitability, and investment. On the other hand, the companies with higher future earnings will have higher stock market returns. This problem has always been finding a proxy today that predicts earnings tomorrow. Then, Novy-Marx (2013) identifies a proxy for expected profitability that is powerful and strongly related to average return. These are the reasons that Fama and French come to examine a model that adds two new factors to the three-factor model,

$$
\begin{aligned}
\mathrm{R}_{\mathrm{it}}-\mathrm{R}_{\mathrm{Ft}}= & \mathrm{a}_{\mathrm{i}}+\mathrm{b}_{\mathrm{i}}\left(\mathrm{R}_{\mathrm{Mt}}-\mathrm{R}_{\mathrm{Ft}}\right)+\mathrm{s}_{\mathrm{i}} \mathrm{SMB}_{\mathrm{t}}+\mathrm{h}_{\mathrm{i}} \mathrm{HML}_{\mathrm{t}}+ \\
& \mathrm{r}_{\mathrm{i}} \mathrm{RMW}_{\mathrm{t}}+\mathrm{c}_{\mathrm{i}} \mathrm{CMA}_{\mathrm{t}}+\mathrm{e}_{\mathrm{it}}
\end{aligned}
$$

In equation (2), $R_{i t}$ is the total return of individual stock/portfolio, $\mathrm{R}_{\mathrm{Ft}}$ is the risk free asset return, and $\mathrm{R}_{\mathrm{Mt}}$ is the total market portfolio return; $\mathrm{SMB}_{\mathrm{t}}$ is the size premium (small minus big), $\mathrm{HML}_{\mathrm{t}}$ is the value premium (high minus low), $\mathrm{RMW}_{\mathrm{t}}$ is the profitability premium (robust minus weak), and $\mathrm{CMA}_{\mathrm{t}}$ is the investment premium (conservative minus aggressive). Table1 shows the abbreviation in the portfolio forms.

TABLE I. ABBREVIATION IN THE PORTFOLIO FORMS

\begin{tabular}{|c|l|}
\hline Abbreviation & \multicolumn{1}{c|}{ Description } \\
\hline$B$ & $\begin{array}{l}\text { Book equity at the end of the fiscal year ending in } \\
\text { year t_1 }\end{array}$ \\
\hline$M$ & $\begin{array}{l}\text { Market capitalization } \text { at the end of December of } \\
\text { year t_1 }\end{array}$ \\
\hline$B / M$ & Book equity to market equity ratio \\
\hline$O P$ & $\begin{array}{l}\text { Operating profitability measured by revenues } \\
\text { minus cost of goods sold, minus selling, general, } \\
\text { and administrative expenses, minus interest expense } \\
\text { all divided by book equity. }\end{array}$ \\
\hline Inv & $\begin{array}{l}\text { Investment } \text { measured by the change in total assets } \\
\text { from the fiscal year ending in year t-2 to the fiscal } \\
\text { year ending in t-1, divided by t-2 total assets. }\end{array}$ \\
\hline
\end{tabular}

Next, Fama and French (2015) define three sets of factors to test the stock performance. Firstly, the approach is like the three-factor model with profitability and investment factors defined like the value factor of that model. Secondly, to test the sensitivity of asset pricing results to the $2 * 3$ sorts on Size and $\mathrm{B} / \mathrm{M}$, they innovatively construct versions of $\mathrm{SMB}$, HML, RMW, and CMA with $2 * 2$ sorts on Size and B/M, OP, and Inv. Finally, the stocks are sorted independently into two Size groups, two B/M groups, two OP groups, and two Inv groups, and this propose of this $2 * 2 * 2 * 2$ sort is to better isolate the premiums in average returns related to these four factors.

\section{ASSESSMENT FOR METHODOLOGY}

In the above procedure, Fama and French (2015) initially employee the GRS approach to address certain aspects of the problem, which facilitates the understanding why different financial assets earn immensely different returns on average. This methodological approach builds on the notion that whether intercept is incapable of being perceived as different from zero in a multiple regression on the model's factor returns [11]. In brief, the GRS test technique captures the relative deviations of the given portfolio from the ex post efficient portfolio in terms of the Sharpe ratios, and once an asset pricing model can completely capture expected returns, the estimated intercepts are jointly zero. "This approach can even be considered as a form of tautology, because they use five factors to explain the returns of those same five factors".

According to Fama and French's (2015) call, the propose of regression test is to observe whether the five factor model captures average returns on the variables and to see which variables are positively or negatively correlated to each other and additionally identifying the size of the regression slopes and how all these factors are related to and affect average returns of stocks values. Fama and French (2015) widely 
took seven models in account and addressed the regression details to explain many patterns in average returns with size, $\mathrm{B} / \mathrm{M}$, profitability and investment factors, and further except that one portfolio can show up in many sorts. However, the results show that all models show the incomplete descriptions via the GRS test. The significant problem for the five-factor model is the portfolio of small stocks in the lowest profitability and highest investment quartiles.

\section{DISCUSSION}

\section{A. Findings}

This paper presented a five-factor asset pricing model, which extended the three-factor model by incorporating two additional factors that captured profitability and investment. Firstly, their article does fill a gap in the literature on these two quality factors and document important and robust results between the average returns and these factors. Secondly, the proposed model demonstrates that the investment factor has a high correlation to the value and profitability factors. However, the model's performance is not sensitive to the way its factors are defined. The value factor (HML) becomes redundant for describing average returns and the result shows that a four-factor model that drops HML performs as well as the five-factor model. Overall, this five-factor CAPM has proved to be an enormous improvement compared to previous models but has also left room for better models to be further developed from it in the future [5].

\section{B. Limitations}

There are a few limitations and questions in this process, which are worth to concern in future researches. Firstly, the results reveal that the highest returns can be expected from companies that are small, value (high book-to-market), and profitable that are not embarking on major growth initiatives. Therefore, it is favorable and interesting to examine whether this phenomenon shows up in the international data. In the practical situation, if a company announces they are about to invest a large amount of money in a new scheme, is that good news or bad news? As an investor, should you be more prone to buy or sell its stocks? On the basic of above problems, it is hoped that the overlap among new issues will be improved in future inquiry. Future researches could apply greater use of the theoretical and qualitative methods to investigate the relationship between risk and stocks return.

Secondly, it is noteworthy that the momentum and liquidity effects do not include and augment in this work. Fama and French (2014) examined that momentum and liquidity factors come into being the trivial changes. However, it is not like an ordinary style that we test of efficient markets in weak form or semi-strong from. On the one hand, only when the left-hand-side portfolios are formed on momentum factors is including a momentum factor imperative [8]. On the other hand, there is evidence to suggest that except for the market factor, all of the factors including liquidity are not significant at even the 5\% level using their approach [21]. Specifically, Racicot and Rentz (2016) verify the five-factor model and compare this model to a six-factor model that includes the liquidity factor [17]. They indicated that the five-factor model seems quite effective in explaining the returns via the method of ordinary least squares. However, the explanatory power of this model substantially weakens when using the generalized matrix method, not excepting liquidity.

Thirdly, this five-factor asset pricing model has to confront a potentially noticeable problem that the low average returns of small stocks that invest a lot despite low profitability. Thus, future research can intend to investigate some empirical evidence to shed some light on this issue and whether the phenomenon exists in China or the other emerging countries. As we know, conspicuously missing are published literature and research studies of evaluating the latent factor in Chinese stock markets in a data rich environment.

Finally, the recent study indicates a profitability factor excluding or including accruals and indicated the "accruals anomaly" that some firms with high accruals generate lower returns than firms with low accruals [3]. They intend to explain high average returns for profitable firms, but any increase in profitability that is solely due to accruals does not have the relation with the cross section of expected returns. However, they do not explicate that accruals add noise to earnings or are otherwise detrimental to performance measurement. Therefore, this issue has to receive a lot of attention in the literature and continues to be a subject of ample debate; that is to say, a potential problem of asset pricing models may be whether cash-based profitability can provide a stronger signal of future returns in small stocks.

\section{CONCLUSION}

This current paper reviews the Fama and French's new five-factor model and provides insights into exploring profitability and investment as good proxies for risk factors, then gives some compact assessment for methodological approach. In fact, when using indicators of profitability and investment to evaluate their impacts between risk and stock returns, however, we need to carefully distinguish investors to use this method depending on the nature of the application. In short, this five factor Fama-French model has taken one more step toward establishing itself as a major field of asset pricing models and offered favorable and important research areas for further inquiry.

\section{REFERENCES}

[1] Aharoni G, Grundy B, Zeng Q, "Stock returns and the Miller Modigliani valuation formula: Revisiting the Fama French analysis", Journal of Financial Economics, vol.110, no.2, pp. 347-357, 2013.

[2] Ang, A., Hodrick, R. J., Xing, J., and Zhang, X., "The cross-section of volatility and expected returns", Journal of Finance, vol.51, pp.259-299, 2006.

[3] Ball R, Gerakos J, Linnainmaa J T, et al., "Accruals, cash flows, and operating profitability in the cross section of stock returns", Social Science Electronic Publishing, vol. 121, no.1, pp. 28-45, 2016. 
[4] Cochrane J H., Asset Pricing Theory, Princeton University Press, 2009.

[5] Fama E F, French K R., "A five-factor asset pricing model", Journal of Financial Economics, vol.116, no.1, pp. 1-22, 2015.

[6] Fama E F, French K R., "Common risk factors in the returns on stocks and bonds", Journal of Financial Economics, vol.33,no.93, pp. 3-56, 1993.

[7] Fama E F, French K R., "Dissecting Anomalies with a Five-Factor Model", Review of Financial Studies, vol.29, no.1, pp. 69-103, 2016.

[8] Fama, E., French, K., "Dissecting anomalies", Journal of Finance, vol. 63, pp. 1653-1678, 2008.

[9] Fama, E., French, K., "Profitability, investment, and average returns". Journal of Financial Economics, vol.82, pp. 491-518, 2006.

[10] Fama, E., French, K., "Size and Book-to-Market Factors in Earnings and Returns", Journal of Finance, vol.50, no.1, pp:131-155, 1995.

[11] Gibbons M R, Shanken J., "A Test of the Efficiency of a Given Portfolio", Econometrica, vol.57, no.5, pp. 1121-52, 1989.

[12] Hou K, Xue C, Zhang L., "Digesting Anomalies: An Investment Approach", SSRN Electronic Journal, vol.28, no.3, 2012.

[13] Ikenberry D, Lakonishok J, Vermaelen T., "Market underreaction to open market share repurchases", Journal of Financial Economics, vol.39,no.39, pp. 181-208, 1995.

[14] Jegadeesh N, Titman S., "Returns to Buying Winners and Selling Losers: Implications for Stock Market Efficiency", Journal of Finance, vol.91, no.48, pp. 65-91, 2015.
[15] Lakonishok, J., Shleifer A., and Vishny, R. W., "Contrarian Investment, Extrapolation, and Risk", Social Science Electronic Publishing, vol.49, no.5, pp. 1541-1578, 1994.

[16] Loughran, T. and Ritter, J. R., "The New Issues Puzzle”, Journal of Finance, vol.50, no.1, pp. 23-51, 1995.

[17] Luboš Pástor, Robert F. Stambaugh, "Liquidity Risk and Expected Stock Returns", Social Science Electronic Publishing, vol.111, no.3, pp. 642-685, 2001.

[18] Merton R C., "An Intertemporal Capital Asset Pricing Model" Econometrica, vol.41,no.5,pp. 867-87, 1973.

[19] Miller M H, Modigliani F., "Dividend Policy, Growth, and the Valuation of Shares", Journal of Business, vol.34, no.4, pp. 411-411, 1961.

[20] Novy-Marx, R., "The other side of value: The gross profitability premium”, Journal of Financial Economics, vo.108, pp. 1-28, 2013.

[21] Racicot F, Rentz W F., "Testing Fama-French's new five-factor asset pricing model: evidence from robust instruments", Applied Economics Letters, vol.23,no.6, pp. 1-5, 2015.

[22] Sharpe, William F., "Capital asset prices: A theory of market Equilibrium under conditions of risk", Journal of Finance, vol.19, no.3, pp. 425-442, 1964.

[23] Sloan R G., "Do Stock Prices Fully Reflect Information in Accruals and Cash Flows About Future Earnings?", Social Science Electronic Publishing, vol.71,no.3, pp. 289-315, 1996.

[24] Titman S, Wei K C J, Xie F., "Capital Investments and Stock Returns", Journal of Financial \& Quantitative Analysis, vol.39, no.4, pp. $677-700,2004$ 